\title{
LINGUAGEM: NATUREZA OU CONVENÇÃO?
}

\author{
João Pedro Mendes
}

Universidade Nacional de Brasnia

\begin{abstract}
One of the oldest of problems is to establish the way language arose from the manipulation of sounds used to name things. Plato's dialogue Cratylus was the first work to discuss this subject Two confilcting theorles are presented: Cratylus asserts that names are attached to things by their very nature, that is, each entity demands for itself the name that men give it the reason for its name is in tis nature. Hermogenes refutes this position stating that the relationship between name and named object is a pure convention or an agreement between speakers.

Called upon to decide the issue, Socrates, ater expressing reservations about the positions of the two debaters, presents a third theory: it is the use for the formation and acceptance of a vast store of names what makes possible the relationships of men among themselves and of men with thlngs. Names are fixed in order to instruct, existing in this process an art and artists: the legislators.

Epicurlanism explains the formation of language by sociological and psychologlcal factors. Modern linguists, following Saussure, definitively resolve the problem of the natural or conventional origin of language by setting up varlous points of departure such as: the distinction between language and spee$\mathrm{ch}$, the concept of language as an ideosyncratic system of signs, the arbltrary nature of signs, etc.
\end{abstract}


Conhecer é apreender as imagens dos objetos. A palavra $\theta$ a representação do pensamento $\theta$ do ser. De palavras se entretece a linguagem, que $\theta 0$ meio essencial da manifestaçăo do ser.

Etimologicamente, o termo que designa o ato ou efeito de articular palavras, isto 6 , falar, provém do latim fari, que tem a mesma raiz do grego $\varphi \eta \mu \iota ~ o$ qual originariamente significava "tomar visivel", donde "manifestar o seu pensamento pela fala". Fábula, fama, facundo, fado (primitivamente "declaraçáo", "oráculo"), fátuo ("tagarola"), afasia, eufemismo, inefável, infando, infante, nefando, professor, profeta ("aquele que transmite pela palavra a vontade dos deuses") - são da mesma famflia

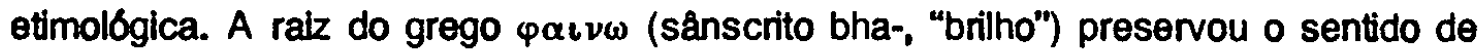
"fazer brilhar", "fazer aparecer", "tornar visivel", "dar a conhecer", "indicar", sentido esse bem patente em face, facho, fagulha, fanal, fanático ("o que se diz lluminado"), fanerogâmico, fantasma, farol, fase ("aspecto"), diâfano, epifania, etc.

A fala, por conseguinte $\hat{e} 0$ ato ou efeito de iluminar, revelar, mostrar o que está oculto. Em sua essência, ela é fenomenológica (mais um vocábulo da famfia), quer dizer, é uma revelação em si mesma que, ao manifestar o revelado, o faz manifestar-se a si próprio nessa mesma luz. Para desvelar o que está escondido, tem de desvelar-se a si mesma, à maneira do claråo, cuja finalidade năo é mostrar-se a si, mas o seu mostrar-se consiste em mostrar o que através dele se mostra. A fala se define por oposição à realidade de que é manifestaçăo: o pensar - e este se manifesta na fala.

Como revelaçáo do pensamento, 0 ato de falar é exclusivo do homem, inscrevendo-se entre as manifestaçőes de sua atividade simbólica, ou seja de sua aptidão para representar as coisas, as ldélas e os fatos por meio de simbolos, que são os sons emitidos por seu aparelho fonador. A fala insere-se no conceito mais amplo de linguagem, a qual, alem de sons, pode utilizar gestos, atitudes, comportamentos, sinais e objetos que substituam o representado, seja ele concreto ou abstrato. Em sentido lato, essa aptidáo năo é exclusiva da espécie humana; estudiosos como o professor K. von Frisch mostraram que as abelhas de um enxame são capazes de simbolizar o ritmo $\theta 0$ sentido de suas evoluçరes em tomo do favo, bem como a duraçáo do voo $\theta$ sua orientaçăo em relaçăo ao sol. Animais gregánios como os castores, certas espécies de aves e as fomigas, por exemplo, podem dispor de verdadeiros codigos, que săo modos análogos de comunicaçăo. Contudo, a linguagem humana tem de especffico o seu caráter complexo; cada simbolo por ela utilizado é decomponivel em unidades menores, podendo estas combinar-se de maneiras diferentes na constituiçáo de novos símbolos, praticamente ad infinitum. Aqueles códigos, pelo contrário, săo fixos e imutáveis, com possibilidades expressivas radicalmente limitadas, na mesma linhas dos hábitos altmentares, dos modos de locomoçăo, construçăo de ninhos ou reproduçáo. Outra distinçăo básica está no fato de a linguagem humana, enquanto ato individual, ser aprendida e náo herdada. Além disso, os grupos humanos podem mudar de sistema de comunicaçăo, o que, aliás, já ocorreu algumas vezes na história da civilizaçóos. Tudo isto sem falar na sua funçăo cognitiva que, esta sim, é insubstitutivel.

Quando o homem primitivo começou a ter consciência do mundo circunstante, uma longa marcha se iniclava rumo ao infinito do ser $\theta$ do poder. O homo saplens passou a captar a nova dimensåo dos objetos da realidade. Num esforço demiúrgico, 
o homo faber passou a agir sobre esses objetos, adaptando-os e transformando-os para satisfazer suas necessidades materiais e espirituais. Num esforço mals ousado, procurou conhecer $\theta$ entender a constituiçăo do cosmos. Naturalmente, a primeira atitude da sua inteligência perante a realidade envolvente é um impulso cognitivo que "totografa" os objetos e imprime suas imagens na mente. A memória $\theta$ o processo evocador constituem os meios $\theta$ as técnicas do conhecimento. Os sentidos recolhem $\theta$ enviam ao intelecto paciente as impressర̋ criadora $\theta$ metamorfoseiam o real. A mente do homem gera $\theta$ povoa um mundo novo, 0 das imagens. Tudo será pretexto para essa atividade genesfaca, da necessidade banal da subsistência ao esconjuro dos maleffcios advindos dos astros e de reinos desconhecidos.

Ora, a expressão da imagem é a palavra. Qualquer tentativa de estruturaçăo de uma ontologia da linguagem terá de apoiar-se na análise do jogo combinatório entre a palavra $\theta$ a imagem. Esta pode ser considerada no estado ôntico de exteriorizaçáo de uma essência (imagem expressiva) e no estado ontológico de sua formaçăo na mente do sujelto falantè, a partir de $\theta$ em referência à realidade de (imagem intencional, no sentido da intencionalidade que Franz Brentano extraiu da escolástica e passou à fenomenologia de Husserl). A palavra $\theta .0$ ser eståo (ntima $\theta$ indissociavelmente unidos, na medida em que ela 0 contém $\theta$ transporta enquanto 0 exprime $\theta$ revela. $O$ valor expressivo da palavra em relaçăo à essência das coisas provém exatamente do fato de aquela conter esta, em mútua $\theta$ inelutável realizaçăo (o pensar $\theta$ matriz $\theta$ fruto, vivendo na e da palavra, ao mesmo tempo).

A palavra é ser e pensar. O pensamento nutre-se da palavra e mora dentro dela ("a palavra 6 a casa do ser"), o mesmo $\theta$ dizer, o pensamento alimenta-se de ser ma palavra $\theta$, numa involução reclproca, a palavra $\theta$ produto do pensamento.

Descendo a um terreno menos especulativo, vejamos como se deu, na história do homem, a nomeaçăo das colsas pela fala; em outros termos, a origem da linguagem, segundo os pensadores clássicos. Refletindo sobre este ponto, talvez possamos admitir que o homem, em sua primeira experiência de ser-falante-nomeador de objetos, năo se vale dos signos de forma tăo arbitrária quanto alguns dos modernos ingüistas afiançam. Antes, porém, transcrevamos como eplgrafe estes versos:

Sim, o nome dum ser $\theta$ o próprio ser

Miraculosamente transfundido,

Para sonora imagem cristalina.

Nomear uma coisa é despertá-la,

Tentar a própria esfinge...

Quando nos paira um nome à flor dos láblos

Chega junto de nós, como em segredo.

Invisivel espirito vivente.'

1 - Telxelra de Pascoals, Regresso ao Paralsa, dt por Celestino Pires. Vd. Biblografia. 
Platåo, em seu diálogo Crátilo (387c), póe na boca de Sócrates uma notável definiçăo de linguagem: dar nome às coisas, ou seja, falar é uma forma de atividade pela qual o homem trava relaçరes com os objetos. A comunicaçăo $\theta$ a compreensáo entre os humanos năo são expressamente consideradas por Sơcrates na análise primordial do fenómeno da linguagem.

O nome dados aos seres $\theta$ instrumento que serve para instruir ${ }^{2}$ e também para distinguir a realidade. Tal como a faca serve para cortar, a naveta para tecer $\theta 0$ trado para furar, assim o nome $\theta$ o utenshio adequado para que os homens se instruam uns aos outros $\theta$ discimam as coisas de acordo com sua natureza. Nesse ponto se insere a grande discussăo do diálogo platónico.

Sócrates é convidado pelos interlocutores Crátilo e Hermogenes para arbitrar a disputa: o primeiro sustenta que os nomes são adequados às coisas por natureza ( $\varphi v \dot{\sigma} \sigma \iota$ ); o segundo, que a correspondência entre nome $\theta$ objeto nomeado é simples

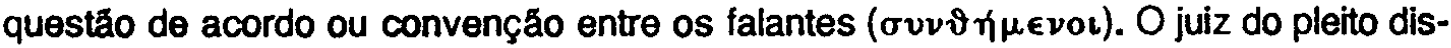
corre em duas fases distintas, advertindo primeiramente para o carácter permanente da realidade, o qual independe de cada um de nós, não cabendo por isso a qualquer dar

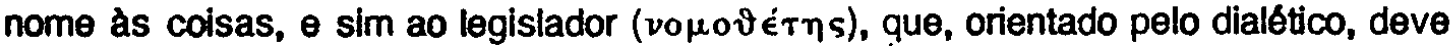
coadunar-se em sua tarefa com as exigênclas do objeto nomeado. Contrariando Hermógenes, o nome parece ter uma certa congruência com a natureza da coisa nomeada. O problema está em saber em que consiste essa congruência.

Autorizado pelos dois contendores, Sócrates enceta uma longa exposiçăo em que a fantasia se mescla à criatividade para explicar os étimos de uma grande lista de nomes derivados. Nessa busca ele identifica os nomes primitivos, partindo entăo para a análise das letras $\theta$ do seu valor, as quais integram sllabas que por sua vez compoem substantivos e verbos que tecem o discurso, $\Theta$ chegando à conclusăo de que o legislador criou para cada ser um signo e um nome, compondo-se tudo o mais com base neles.

Até aqui argüiu contra a opiniăo de Hermógenes. Na segunda fase do debate, vai objetar contra a de Crátilo, disclpulo de Heráclito. Afinal, a prática $\theta$ a convençáo intervêm amiúde na formaçăo de muitos nomes, pelo que estes podem ter uma adequaçăo imperfeita às coisas. Por isso, para conhê-las bem, $\theta$ melhor dirigir-se diretamente a elas do que aos nomes que as designam (438e). O nome entravaria a cogniçấo.

Sócrates năo toma partido por nenhum dos contendores. Antes, como juiz imparcial, opoe reservas a ambas as teses, contrapondc-lhes, no fim de contas, a sua propria, que é a de abrir amplo espaço ao uso na formaçăo e aceitaçăo de um vasto acervo de nomes que possibilite as relaçס̋es dos homens entre si e com as coisas.

A metodologia proposta por Sócrates, na primeira etapa do diálogo, parte da

2 - No Crátilo (436a), Sócrates estabelece uma clara distinçấo entre o conhecimento acabado ( $\mu \alpha \vartheta \in i \nu)$, que năo implica busca, dominio, e a investigaçăo pessoal ( que leva à conquista do conhecimento proprlamente dito. Essa contraposiçáo é bem patente em outro

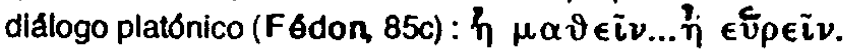


evidéncia de que é impossível reconhecer a adequaçăo dos nomes derivados se igno-

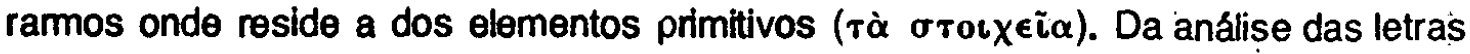

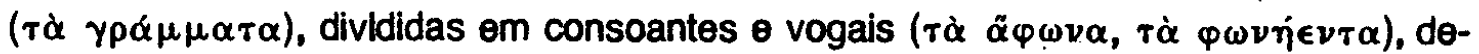

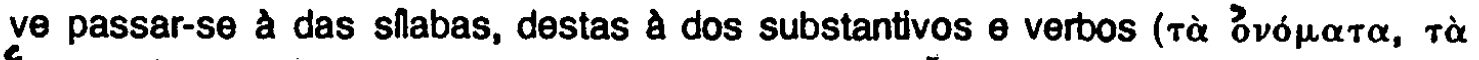

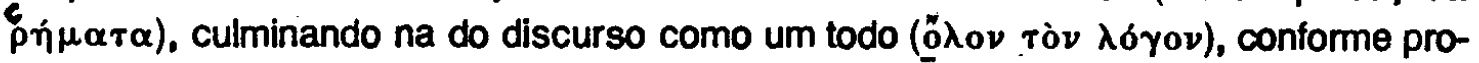
cedem os estudiosos dos ritmos $(424 \mathrm{bc})$. O exame da constituiçăo primária das palavras amplia-se para atingir as unidades sintagmáticas $\theta 0$ texto final. Primeiramente, há

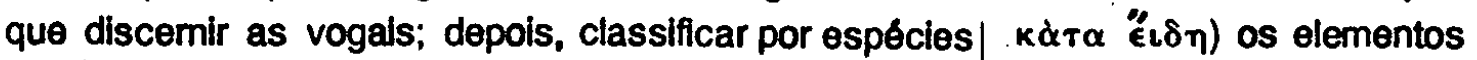
que năo comportam nem son ( $\left.\boldsymbol{\alpha}^{\alpha} \varphi \omega v \alpha\right)$ nem voz ( $\left.\alpha \dot{\alpha} \varphi \vartheta 0 \gamma \gamma \alpha\right)$. Em seguida, deve passar-se à distinção dos elementos que năo são vogais nem comportam ruldo. Depois de bem estabelecidas essas distinçőes será possivel a atribuição, por semelhança ( $\alpha \alpha \tau \dot{c}$

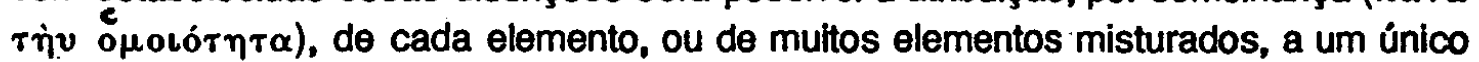
objeto. É necessário distinguir ainda, por sua vez, todos os seres a nomear, procurando saber se podem ser agrupados em categorias e espécies. Assim fazem os pintores para imitarem com as tintas as cores da natureza.

Mas como explicar as coisas pelas letras e sflabas que as imitam? Segundo a tese de Crátilo, isso é uma implicaçăo essencial. Ora, seria ridiculo apelar para o artiffcio dos autores trágicos quando preçisam livrar-se de embaraços na conduçăo da

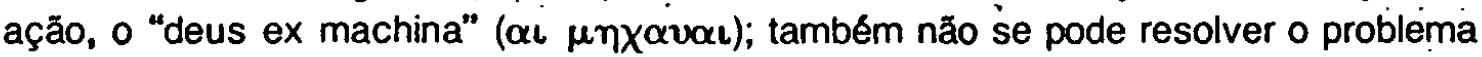
afimando que os nomes primitivos ( $\pi \rho \tilde{\omega} \tau \alpha$ ó $\nu o ́ \mu \alpha \tau \alpha)$ foram fixados pelos deuses, cuja autoridade justificaria sua congruência; outra salda inaceitável seria dizer que vieram dos povos bárbaros, mais antigos que os gregos; ou ainda que sua antiguidade toma impossivel o exame, tal como sucede aos nomes bárbaros.

Por conseguinte, a justeza dos nomes primitivos val ser esclarecida por S6crates através da análise de algumas letras: 0 p e o instrumento adequado para exprimir a

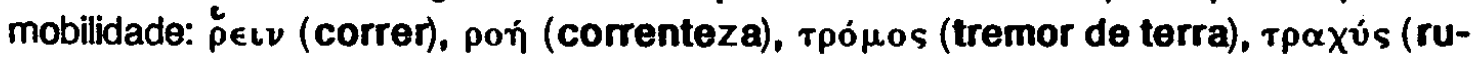

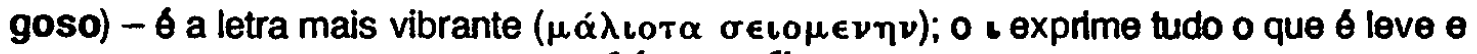

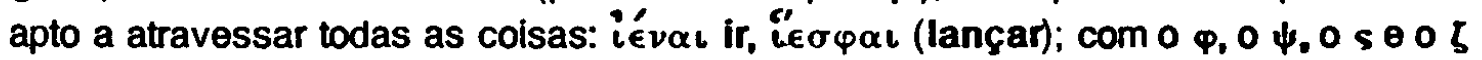
(letras "aspiradas"), o autor dos nomes imitou tudo o que tem esse caráter, como $\psi v-$

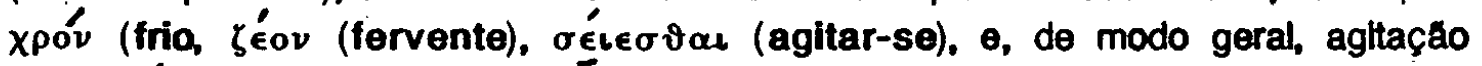
( $\left.\sigma \in \iota \sigma \mu o^{\prime}\right)$ ) $\theta$ ventosidade ( $\left.\varphi v \sigma \overline{\bar{\omega}} \bar{\delta} \epsilon s\right) ; 08$ o 0 T pareceram-lhe apropriados a ex-

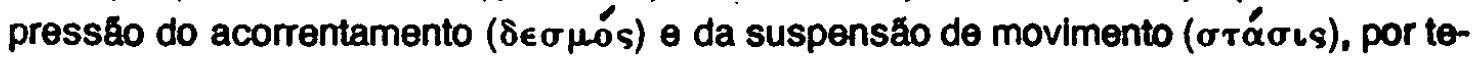
rem o efelto de comprimir a lingua e nela se apoiar, o $\lambda$, em cuja articulaçáo a lingua

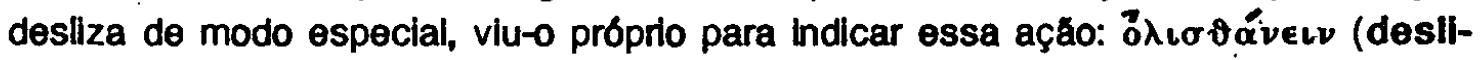

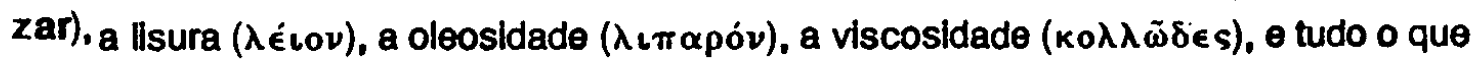

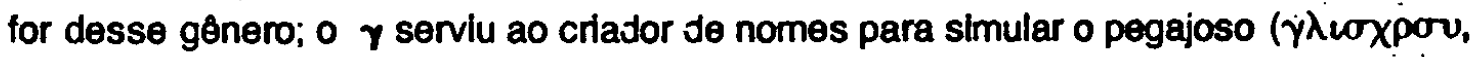

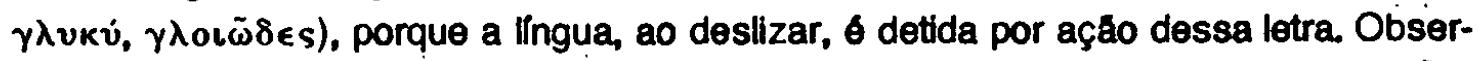

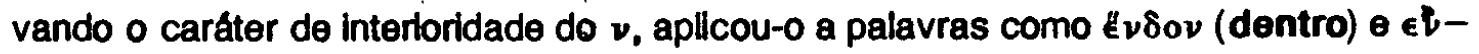
rós (interior), pois em sua prolaçáo ressoa na cavidade das narinas. $O \alpha$ atribulu-o

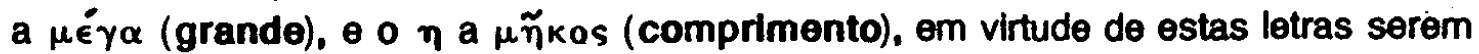
"longas". Ao o achou-o indicado para designar a rotundidade ( $o v \gamma v \lambda o ́ v)$. É obvio que Sócrates, nestas três últimas letras, năo considerou o aspecto fonético, mass 
apenas a forma dos sinais que as representam, como se incidisse no absurdo anacronismo de a escrita preceder a fala. É perfeitamente admissivel que, no caso do o, Socrates visualizasse a conformaçăo dos lábios em sua pronúncia. Aqui está a razão da congruência dos nomes com as coisas designadas por eles, ou seja, essa congruência consiste em fazer ver a natureza dos objetos.

Os modernos fonólogos têm, portanto, no Crátilo o primeiro tratado de sua especialidade, antecipando-se em mais de dois mil anos às investigaçరos de Leibniz $\theta$ Jacob Grimm e podendo estimular as reflexס̋es de especialistas no estudo da linguagem como Prieto, Bloomfield, Sapir, Trubetzkol, Hjelmslev, Jakobson, Siewerth $\theta$ Martinet, para citar apenas alguns de nossos dias.

Durante o diálogo com Hermógenes, Sócrates acha, a certa altura, que the ocorreram idéias engenhosas para discorrer a propósito dos nomes. Diz que, muitas vezes, para formá-los, acrescentamos ou suprimimos letras, derivando os nomes de onde nos apraz, e deslocamos os acentos. Dá como exemplos, entre outros, os nomes dos homens $(\alpha \nu \vartheta \rho \omega \pi o l)$, da alma $(\psi v \chi \chi)$, do corpo $(\sigma \tilde{\omega} \mu \alpha)$ e do sinal $(\sigma \tilde{\eta} \mu \alpha)$. O homom foi chamado de $\stackrel{\|}{\alpha} \nu \rho \omega \pi$ ros porque, ao contrário dos animais que são incapazes de observar o que vêem, de raciocinar sobre isso e examiná-lo, ele examina o que viu

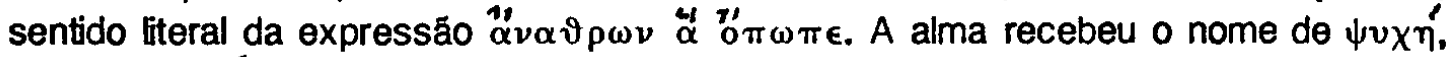
derivado de $\alpha_{\alpha}^{\prime} v \alpha \psi v \chi \chi^{\prime} v$ ("que reanima com ar fresco", "refrescante"), por ser causa da vida para o corpo, conferindo-the o poder de respirar, faltando esse princípio vital, o como definha e morre; $\theta$ o esplrito ( $\nu$ ovs) e a alma ( $\left.\psi v \chi \chi \eta^{\prime}\right)$ que ordenam $\theta$

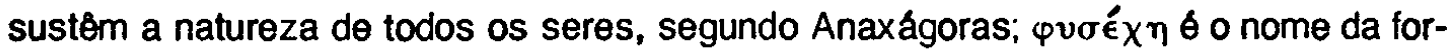

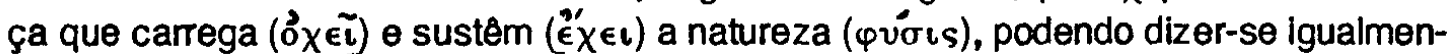

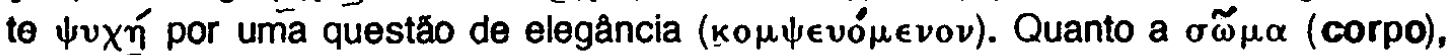
Socrates acha este nome muito complexo, lembrando que alguns o definem como túmulo $(\sigma \tilde{\eta} \mu \alpha)$ da alma, onde se encontraria presentemente sepultada; por outro lado, o corpo $\theta$ o sinal $(\sigma \tilde{\eta} \mu \alpha)$ que indica as manifestaçőes da alma. Diga-se, entre parênteses que $\sigma \eta^{2} \mu \alpha$, quiçá do sânscrito dhyama, significava também "sinal com que se

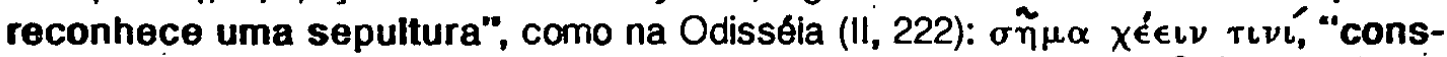

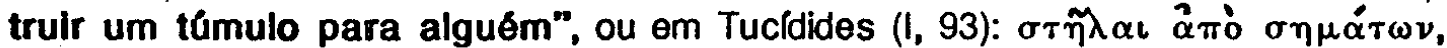
"colunas funerárias que se elevam do chăo das sepulturas". Contudo, Sócrates inclina-se para a explicação dada pelos seguidores dos mistérios órficos: uma vez que a alma foi punida por culpas cometidas, $\theta$ o corpo que a guarda $(\sigma \omega \zeta \in \tau \alpha \iota)$ até à expiaçáo total, como se fora um cárcere. (Em Homero, $\sigma \tilde{\omega} \mu \alpha$ significa corpo morto, cadáver - Illada, VII, 79; Odisséla, XI, 53, etc.)

A pedido de seu interlocutor, Sócrates começa a explicar os nomes dos deuses, na mesma linha em que já explicara o de Zeus. O mesmo com os nomes dos astros $\theta$ elementos da natureza, assim como de virtudes e noçరes morais, num total aproximado de 140 etimologlas.

Rebatida até certo ponto a tese de Hermógenes, entra em cena Crátilo, cuja teona val receber, por seu turno, as criticas e restriçסes de Socrates, que passa a desartcular suas próprias congeminaçరes anteriores, após captar a benevoléncia de seu novo interlocutor oferecendo-se-Ihe candidamente como disclpulo (428 b). 


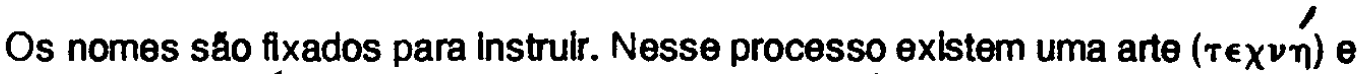

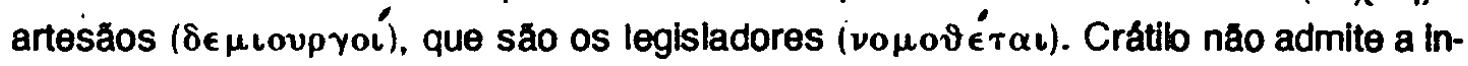
congruência dos nomes com as coisas; todos eles assentam perfeitamente aos seres

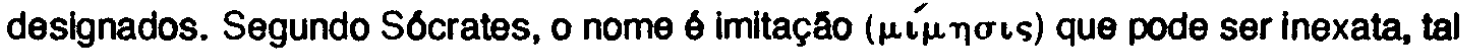
como a pintura pode ser infiel à realidade que procura reproduzir. Tal como existem bons $\theta$ maus pintores, que executam bons $\theta$ maus retratos, assim também há bons $\theta$ maus legisladores, que estabelecem com justeza ou năo os nomes das coisas. Quem sejam esses nomotetas não é explicitado. Uns intérpretes dizem que é o povo, tomado coletivamente, o criador por excelencia da linguagem; outros pretendem que seja um deus, um heroi divinizado ou personagem mítico; outros, finalmente, pensam que Socrates se referia aos primeiros homens dotados de fala. Fosse quem fosse, esse legislador haverla de possuir uma poderosa imaginaçăo secundada por forte capacidade mimétical, para criar metáforas ou transferéncias do tipo das onomatopélas, que recriam na prolaçăo dos sons da fala o objeto significado. Todavia, mesmo assim, a imagem corre o risco de ser copla infiel do objeto, podendo induzir em erro.

Os nomes, segundo Crátilo, seriam uma representaçăo $(\delta \eta \hat{\lambda} \omega \mu \alpha)$ do objeto mediante letras $(\gamma \rho \alpha \mu \mu \mu \alpha \tau)$ e sllabas ( $\sigma \nu \lambda \lambda \alpha \beta \alpha \hat{i})$, mas não existirá nome propriamente dito se nessa pretensa representaçáo náo estiverem presentes todas as caracteristicas do objeto. Este o lado vulnerável da tese que Sócrates explora, levando seu interlocutor a concordar em que uma imitaçáo aproximativa é preferfvel a qualquer meio surgido por acaso, para representar o objeto. O uso pode levar o falante a perceber a

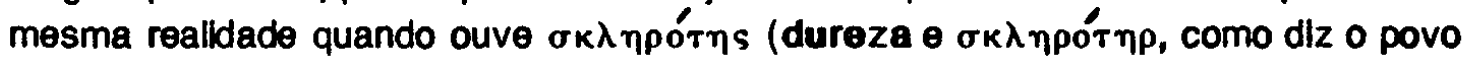
da Eritréla. Isto depols de Crátib convir com Hermógenes em que o p exprime a moblldade; neste e noutros casos, o s desempenha o mesmo papel por semelhança, aproximaçáo. No estabelecimento dos nomes existe, por conseqüencia, uma parte de acor-

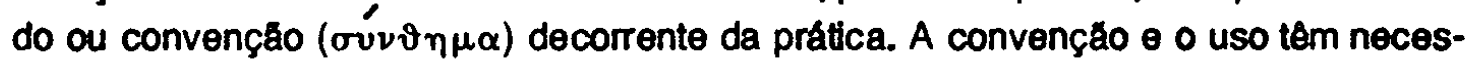
sarlamente de contribuir para a representaçáo do que o homem tem na mente quando fala. Socrates, no entanto, prefere que os nomes sejam o mais possivel semelhantes aos objetos, mas sente-se compelido, multas vezes, a recorrer ao expediente grosseiro

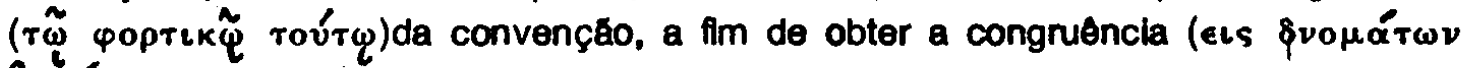

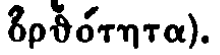

A conclusăo final de Sócrates é pela imprudéncla em esperar dos nomes o conhecimento perfelto das colsas. O melo mais seguro, por ser o mals natural e legitimo, consiste em aprender a conhecer as colsas umas através das outras. Propóe elo a Crátilo a escolha da mals bela e rigorosa forma de conhecimento dentre a altemativa: deveremos partir da imagem (dada pelo nome) para ficar sabendo, através de seu estudo, se a cópla é boa $\theta$, ao mesmo tempo, conhecer a verdade de que ela é imagem; ou deveremos antes partir da verdade para conheceta em sl $\theta$, simultaneamente, conferit $8 \theta$ sua imagem fol adequadamente realizada? Crátilo escolhe, evidentemente, a segunda forma. 
Alguns comentadores procuram em văo, no Crátlla, um conceito de linguagem. A bem da verdade, temos de reconhecer que ele não existe em toda a antiguídade clássica, pelo menos segundo conceituaçăo moderna. O tema amplamente discutido pela filosofia grega e por uma tradiçăo especulativa que vai perdurar pela Idade Média $\theta$ propriamente o da correçáo dos nomes, tema esse, aliás, infra-escrito ao ttulo do diálogo de Platăo. Os sofistas fizeram dele um dos pontos fortes de suas perambulaçסes didáticas. Podemos dizer com segurança que a ausência de uma definiçăo desse conceito rigoroso de linguagem ao tempo de Platáo constitui a causa da conclusáo aporética do fecho do Crátilo.

Epicuro, em sua Carta a Heródoto, que nos foi transmitida por Diógenes Laérclo em Vida, Doutrinas e Sentenças dos Filosofos llustres, ou mais simplesmente, Vidas dos Filosofos; livro $X$, discorre brevemente sobre 0 aprendizado da fala. A natureza aprende por si mesma muitas e variadas coisas, recebendo múltiplas impressరes. A experiéncia e a necessidade aperfeiçoam os conhecimentos recebidos da

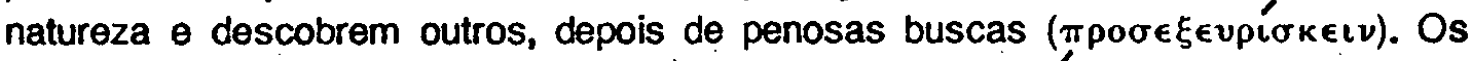

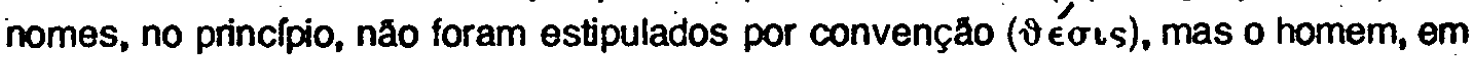
todos os povos, recolhendo as imagens ( $\left.\varphi \alpha \nu \tau \alpha^{\prime} \sigma \mu \alpha \tau \alpha\right)$ das coisas e sofrendo suas

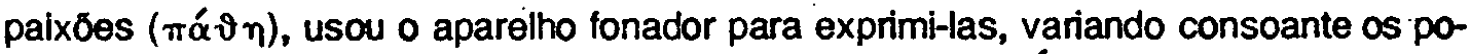
vos e os lugares - esta reação do homem é causada pela púous. Mais tarde, cada povo instituiu uma linguagem própria, comum a todos os seus integrantes, para que náo houvesse equivocos $\left(\alpha_{\alpha}^{\prime} \mu \varphi\left(\beta o \lambda_{i}{ }^{\prime} \alpha\right)\right.$ na designação dos objetos e a expressão fosse

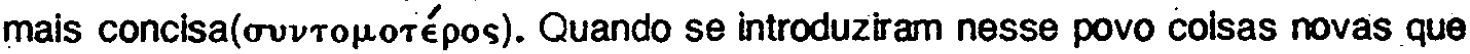
careciam de nome, seus introdutores forneciam as palavras para designá-las. O uso e a reflexåo produziam a incorporação definitiva.

Em sintese, Epfcuro considerava três etapas na origem e formaçăo da linguagem humana:

1) o homem, pela voz, exprime emoçס̋es e percepçס̋es: a pú́ıs é que produz essa resposta instintiva ao mundo que o cerca;

2) intervém entåo a ৩ đéơs, para que os homens se entendam ao designarem os seres;

3) no processo de aquisição e incorporação de nomes novos, conjugam-se $\varphi$ voاs e véơıs.

No fundo, o epicurismo dá para o surgimento da linguagem uma explicaçăo psicologica e sociológica, simultaneamente. As necessidades do homem $\Theta$ que o impelem à emissão espontânea dos sons para nomear os objetos. A constituiçăo do acervo de nomes é feita paulatinamente, num gradual e interminável avanço.

O grande expositor das idélas de Epicuro em Roma é Lucrécio, em seu longo e denso poema Da Natureza das Coisas. Curiosamente, das três etapas de Epicuro no aprendizado da linguagem, considera apenas a primeira (livro $V, 1028-1090$ ). A criança, ainda inepta para exprimir-se com a lingua, recorre ao gesto para apontar com o dedo os objetos que a rodeiam, num processo análogo ao do bezerro quando utiliza os chifres que mal despontam para ameaçar o adversário e arremetê-lo de cabeça baixa; ou ao dos filhotes das panteras e dos lebes, que se defendem com patas, garras 
e presas, antes mesmo que unhas $\theta$ dentes hajam crescido. As aves de toda a espécie ensaiam o voo ainda meio implumes. Lucrécio é pensador $\theta$ poeta, recorrendo ao símile para llustrar que a necessidade (utilitas) impos ao homem o desafio da palavra. A fala $\theta$ o instrumento $\theta$ a arma com que a natureza dotou o ser humano, a característica individuante da espécie. Fol o instinto natural, cuja força reveladora o poeta evoca, o verdadeiro criador da linguagem:

Sentit enim uim quisque suam quoad possit abuti.

Cada hornem, na verdade, tem a percepçao do uso que pode dar esse seu poder(v.1033).

Para Lucrécio, esta á a única explicaçăo da origem da linguagem. Nấo admite a convenção e 0 acordo estranhos ao instinto, quiçá uma concessão da escola epicurista ao racionalismo utilitarista dos homens cultos de Roma. De fato, o epicurismo genuíno privilegiava os aspectos afetivos e emotivos radicalmente associados ao instinto. Lucrécio acha insensatez (desiperest) o procedimento daquele que admite que alguém um dia distrilbuiu nomes pelos objetos e posteriormente os homens aprenderam desse alguém os primeiros rudimentos da linguagem (uocabula prima). Se um individuo pode estipular nomes às coisas e emitir os modulados sons da fala (uarios sonitus emittere linguae), por que não supor que outros poderiam tê-lo feito ao mesmo tempo que ele (resultando numa babélica algaraviada)? Pôr outro lado, é impossivel conceber a utilldade da linguagem sem antes tê-la experimentado. Ademais, como é que um único homem, mesmo genial, poderia ter reunido multidరes e compeli-las a aprender os nomes de todos os seres? E como levaria ele os surdos a suportar que ele thes enchesse os ouvidos dos sons inúteis e desconhecidos da fala (uocis inauditos sonitus obtundere frustra)? Um epicurista tardio, Diógenes de Enoanda, classificou de ridicula a teoria de que a linguagem é obra de convençáo engendrada por uma divindade ou por um homem de gênio.

Ao encerrar o trecho do livro $V$ sobre a origem da fala, Lucrécio volta à tese de que foi a natureza que dotou o homem com a aptidão para dar nomes a todas as cotsas, à maneira dos rebanhos, feras e pássaros, que emitem sons de acordo com as variaçరos sazonais ou o que sentem: medo, ameaça, raiva e carinho, lamento, agouro e euforia. E exclama, interrogando: Se a diversidade das sensaçóes (uarii sensus) compele os animais, mesmo sendo mudos, a emitir sons variados, como não haveria de ser natural que os mortais de antanho pudessem designar diferentes coisas com nomes diferentes!?

Discutindo uma outra questăo - da origem da eloqüência -, Cicero parece contraditar o pensamento lucreciano-epicurista ao excluir o terceiro membro da disjunção interrogativa: a eloqüência será fruto de um ensino teórico (artis, de uma exercttaçăo prática (exercitationis) ou de uma aptidăo inata (facultatis ab natura profectae)? Diz o grande orador que, em tempos idos, os homens erravam pelos campos como os animais bravios. Como estes se alimentavam, sem fazer uso da inteligência, mas da 
força ffsica, para decidir fosse o que fosse. Năo prestavam culto aos deuses, nem tinham deveres uns para com os outros. Năo existia casamento segundo as leis, nem tampouco o conceito de familia ou de justiça igual para todos. Por causa do erro $\theta$ da ignorância, a cobiça impunha seu cego e temeránio império sobre a inteligência, abusando da força corporal em sua tirania.

Ora, nesse tempo remoto - prossegue o Arpinate -, um homem superior $\theta$ sábio reconheceu no espirto da espécie um campo fértil e um pendor acentuado para o cometimento de grandes feitos, se alguém o orientasse na senda da perfeiçăo. Foi ele que, dotado de um talento peculiar, congregou os homens dispersos pelos vales e escondidos em choças de ramagens e os ajuntou num mesmo lugar. Inspirando-lhes tudo - que era útll e moralmente belo, a eles que de inicio recalcitravam por causa da novtdade $\theta$ depois aceitavam com entusiasmo devido à sabedoria e eloqüéncia do guia, de ferozes e selvagens os amansou e civilizou.(De Inuentione, 1,2,il)

O problema da origem natural ou convencional da linguagem só velo a ser definitivamente equacionado a partir de Saussure, o qual delfiniu pela primeira vez um certo número de pontos-chaves que sáo a base dos modemos estudos lingülsticos: distinçấo entre língua e fala, concepçăo de língua como sistema idiossincrónico de signos, carácter arbitrário destes últimos, etc.

Fol Saussure que despertou a necessidade de estudar-se a relaçáo entre os fenomenos fónicos e sua funçăo significativa, tarefa a que se consagraram, entre outros, clentistas do porte de Dufriche, Passy, Winteler, Sweet, Baudouin, Noreen $\theta$ Kruszewskl. Noreen, em suas reflexర̋es, estabeleceu a importante distinção entre estudo substancial $\theta$ estudo formal dos conteúdos semánticos $\theta$ dos aspectos fónicos.

Saussure retomou a terminologia e conceituaçăo escolásticas de ato e poténcla, substância $\theta$ forma, $\theta$ aplicou-as cuidadosamente às entidades lingüfsticas. A fala (parole), resultado da união de uma fonla a um sentido concretos, é substancia; o que se atualiza na fala $\theta$ serve para classificá-la, vale dizer, o conjunto de significados - a lingua - $\theta$ forma. As classes abstratas ou formais, denominadas significantes e significados $\theta$ constitutivas dos signos, são independentes, para sua formaçăo, das caracterfsticas intrínsecas da substância fónica e psicológica. Por outras palavras, elas năo dependem mecanicamente, de maneira determinada, dos caracteres físicos da substâncla. O mesmo se passa com as significaçős $\theta$ os significados. É por isso que as dis-

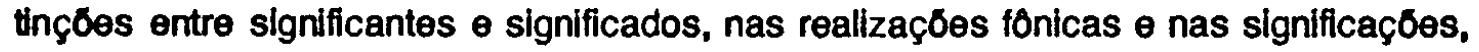
têm um cunho eminentemente arbittário. A capacidade inata da inteligencla humana para discernir $\theta$ associar em classes os atos $\theta$ os dados colhidos por sua experiencia do mundo dos objetos possul ampla liberdade para recortar e estruturar a substancia fôntca, formando classes e coordenando-as a seu criterio.

O patriarca da moderna ciência da linguagem erige em principio básico dé toda a realidade lingülstica precisamente o carácter amitrário do signo. Daqul promanam conseqüênclas de grande alcance. Em primeiro lugar, um principlo de classificaçáo dos 
sistemas semiol6gicos de acordo com o maior ou menor grau dessa arbitrariedade: assim se classificam os sistemas semiológicos dos ritos, usos, costumes, códigos de comunicação, grrias, linguagens de todo o tipo. Em segundo lugar, o princlpio da linearidade, em cuja conformidade a linguagem verbal se processa e que permite a codificaçāo numa seqüência linear das situaçőes que se apresentam unitariamente à memoria, a percepção e ao conhecimento do falante. Pode-se dizer que toda a organizáçăo de uma lingua repousa na intersecção desses dois princípios. O fato de o signo ser arbıtrário explica ainda outros fenómenos importantes, como o da opositividade entre significantes e significado. Por outro lado, o princípio da linearidade está na base do carácter sintagmático das entidades significantes e significadas. O "equilibrio" da língua, na expressão saussuriana traduzida pelos organizadores de seu Curso (Charles Bally e Albert Sechehaye) e mais tarde, por Martinet, como "economia" do sistema, assenta no binómio opositividade-sintagmaticidade dessas entidades, decomponiveis em unidades minimas ("unidades concretas" para Saussure, "monemas" para Frei e Martinet), as quais, junto com os esquemas fundamentais (denominados "abstratos" pelo lingüista su(ço) de sua combinaçбes possiveis, constituem a lingua como sistema global. A lingua produz e cria sempre novos signos cada vez mais complexos, através do grande motor que é a analogia.

Do carácter arbitrário do signo lingüistico provêm ainda dois efeitos antagônicos, mas basilares, para 0 estudo da origem da linguagem. $O$ primeiro $€$ o da mutabilidade de uma língua ao longo do tempo: o segundo, paradoxal, o da contenção dessa mutabilidade. Dado que as entidades semiológicas e sua organizaçăo em sistemas eståo isentas dos grilhőes do mundo dos objetos e năo se vinculam à realidade lógica ou natural, uma lingua incorre fatalmente nas mudanças mais ilogicas e imprevisíveis, entregue aos caprichos do acaso e aos gostos, tendências e opçठes dos sujeitos falantes. Acontecem, por isso, com freqüência, na história comparada de linguas muito diferentes, convergências meramente fortuitas, e, ao contrário, divergéncias notáveis entre provenientes de um mesmo tronco. Isso ocorre, evidentemente, devido ao fato de as linguas sofrerem exclusivamente as limitaçסos impostas ao aparelho fonatório e acústico do homem, bem como à sua capacidade de percepção e consciencialização. Cada lingua tem possibilidade infinitas de combinar significantes e significados, num limitado acervo de fonias e sentidos ao seu dispor.

Outro efeito da arbitrariedade do signo - 0 da contenção das mudanças - opera em sentido inverso, porquanto as fonias $\theta$ as significaçరes, que representam os significantes e os significados de um lingua, estão em continuo processo de mutaçăo, produzindo abalos e oscilaçס̋es que se amortecem nas fronteiras naturais do sistema. Assim. ao mesmo tempo que dá margem a essas mudanças, o arbitrário condiciona, refreia e estabiliza os "desvios" dentro dos parâmetros sistemáticos da língua.

$\cap$ quadro de conseqüências desencadeadas pela arbitrariedade do signo não es taria completo se năo atentássemos no aspecto radicalmente social da língua. $\hat{E}$ o con. senso de uma comunidade que utiliza o mesmo sistema o fator que valida o nexo, de certo modo preexistente, entre os significados $e$ as coisas. $O$ consenso entre seus 
membros organiza livremente os significantes, mas os significados são como que impostos a esse consenso por uma realidade que the $\theta$ anterior. Este carácter eminentemente social da lingua foi explorado com muita argúcia por Wittgenstein, conferindo a esse fator a mesma força para estabilizar e possibilitar as mudanças que assinalamos ao carácter arbitrário do signo. O social freia os caprichos e os devaneios de certos grupos ou individuos, ao mesmo tempo que faz a lingua mudar, sempre que se reduz a exigêncla de distinguir entidades lingülsticas consolidadas ou aparece a necessidade de estabelecer distinçбes novas. 


\section{BIBLIOGRAFIA COMPULSADA}

BENVENISTE, Émile. Problemas de Lingūlstica Geral Trad. de Maria da Giória No vak e Luiza Neri. Sáo Paulo, Companhia Editora Nacional e Editora da Universtdade de Săo Paulo, 1976.

BOYANCÉ, Pierre. Lucrèce et l'épicurisma Paris, Presses Universitaires de FranCe, 1963.

CASINI, N. "Diogene di Enoanda e Lucrezio", Rivista di Storia della filosofia, 4, 1949, p. 287ss.

CICERO. De inuentione. De optimo genere oratorum. Londres, W. Heinemann, 1949.

DIÓGENES LAÉRCIO. Vitae Philosophorum, ed. H. S. LONG, tomus posterior, $X$, Epikouros. Oxford, e Typographeo Clarendoniano, impres. da Oxford University Press, 1966.

ENES, José. À Porta do Ser. Lisboa, Difusáo Dilsar, s. d.

LUCRÉCIO. T. Lucretii Cari De Rerum Natura Libri sex, ed. por Adolhus BRIEGER. Leipzig, 1909.

PIRES, Celestino. "O Ser e a Palavra", recensåo às tres obras de Siewerth, infra, in Revista Portuguesa de Filosofia supl. bibl. $n$ ㅇ 24. Braga, 1961, pp. 302ss.

PLATÃO. Opera, t. I, Cratylus, ed. por loannes BRUNET. Oxford, e Typographeo Clarendoniano, impres. da Oxford University Press, 1973.

PROCLO. Procli Diadochi in Platonis Cratylum Commentaria. Edidit Georgius Pasquali. Lipsiae, in aedibus B. G. Teubnert, 1908.

SAUSSURE, Ferdinand de. Cours de linguistique générale, ed. crfitca por Tullio de Mauro. Paris, Payot, 1972.

SCHAFF, Adam. Linguagem e Conhecimento. Trad. de Manuel Reis. Colmbra, Livraria Almedina 1974.

SIEWERTH, |Gustav. Wort und Bild. Elne ontologische Interpretation Düsseldorf, Verlag Schwann, 1952.

SIEWERTH, Gustav. Die Sinne und das Wort. Düsseldorf, Verlag Schwann, 1956.

SIEWERTH, Gustav:|Das Sein als Gleichnis Gottes. Heidelberg, F. H. Kerle Verlag, 1958. 